\title{
Supplementation of grazing dairy cows with rumen-protected tuna oil enriches milk fat with $n-3$ fatty acids without affecting milk production or sensory characteristics
}

\author{
Soressa M. Kitessa ${ }^{1 \star}$, Suresh K. Gulati ${ }^{2}$, Gillian C. Simos ${ }^{3}$, John R. Ashes ${ }^{4}$, Trevor W. Scott ${ }^{5}$, \\ Eva Fleck ${ }^{6}$ and Peter C. Wynn ${ }^{3}$ \\ ${ }^{1}$ CSIRO Livestock Industries, Underwood Ave, Floreat Park, Wembley, WA 6913, Australia† \\ ${ }^{2}$ Faculty of Veterinary Science B19, University of Sydney, NSW 2006, Australia \\ ${ }^{3}$ Department of Animal Science, University of Sydney, NSW 2006, Australia \\ ${ }^{4}$ Australian Consumer Association, Sydney, Australia \\ ${ }^{5}$ Rumentek Industries, Parkside, South Australia 5001 \\ ${ }^{6}$ CSIRO Molecular Science, North Ryde, Sydney, Australia
}

(Received 28 August 2003 - Revised 23 October 2003 - Accepted 28 October 2003)

\begin{abstract}
The present study was conducted to determine the pattern of incorporation of dietary EPA and docosahexaenoic acid (DHA) into milk, and to evaluate consequent changes in milk fat composition and sensory characteristics. Fourteen multiparous cows in early lactation were divided into two groups and were offered supplements for $10 \mathrm{~d}$. While individual stalls after each morning milking, one group was offered a mixture of rumen-protected tuna oil (RPTO)-soyabean supplement $(2 \mathrm{~kg} ; 30: 70, \mathrm{w} / \mathrm{w}$; +RPTO) and the second group was offered the basal ration without RPTO (-RPTO). Both groups grazed together on a spring pasture after supplementation. Feeding supplemental RPTO increased the concentrations of EPA and DHA in milk fat from undetectable levels in - RPTO cows to 6.9 and $10 \cdot 1 \mathrm{~g} / \mathrm{kg}$ milk fat respectively. Total $n-3$ PUFA concentration in milk fat was increased three- to fourfold by tuna-oil supplementation (8.4 to $32.0 \mathrm{~g} / \mathrm{kg}$ milk fat). There were no significant effects on milk production $(35.4 v .33 .91 / \mathrm{d})$, milk protein $(28.2 v .30 .1 \mathrm{~g} / \mathrm{kg}) \mathrm{or}$ milk fat $(36.2 v .40 \cdot 4 \mathrm{~g} / \mathrm{kg}$ for - RPTO and + RPTO respectively). The concentration of total saturated fatty acids in milk fat was significantly reduced (568v. $520 \mathrm{~g} / \mathrm{kg}$ total fatty acids) and there was a $17 \%$ reduction in the atherosclerotic index of milk after tuna-oil supplementation. Untrained consumer panellists $(n$ 61) rated milk from both groups of cows similarly for taste and smell. We conclude that it is possible to enrich milk with $n$-3 PUFA without deleterious effects on yield, milk composition or sensory characteristics.
\end{abstract}

Grazing: Tuna oil: Eicosapentaenoic acid: Docosahexaenoic acid: Dairy cows

There is increasing evidence that $n-3$ PUFA play important roles in the normal development of infants (Hoffman et al. 1993) and in prevention of CVD in adults (Sheard, 1998; Nordøy et al. 2001). For instance, the 34th Annual Scientific Meeting of European Society of Clinical Investigation forwarded seven conclusions about $n$-3 PUFA and cardiovascular health (Nordøy et al. 2001). The first was that consumption of two fish-containing meals per week is associated with reduced mortality from CHD (Nordøy et al. 2001). Evidence from dietary surveys, however, indicates that daily consumption of $n-3$ PUFA in most developed nations is less than the recommended daily intake $(650 \mathrm{mg} / \mathrm{d}$; Simopoulos, 1991). Since cardiac-related death and illnesses are major health issues in developed nations, there is a need to increase the access to $n-3$ PUFA through enrichment of staple dietary ingredients (meat and milk) with these health-enhancing fatty acids.

Various strategies have been pursued to increase the level of $n$-3 PUFA in the western-style diet. For instance, manufacturers of infant formula milks now fortify their products with fish oil or specific long-chain PUFA (Morgan et al. 1998). The recommended inclusion concentration is about $3.5 \mathrm{~g} / \mathrm{kg}$ (Simopoulos et al. 1999). There is also an increasing variety of fat-modified dairy products (enriched milk, dairy spreads, etc.) appearing on supermarket shelves. Our present approach focused on manipulation of milk fat from ruminant animals to increase its $n-3$ PUFA content through use of rumen-protected oils enriched in $\mathrm{C}_{20}$ and $\mathrm{C}_{22} n-3$ fatty acids. This is because pasture and common supplements used in dairy farms are a poor source of these $n-3$ PUFA. Furthermore, the precursor of

\footnotetext{
Abbreviations: DHA, docosahexaenoic acid; ME, metabolisable energy; RPTO, rumen-protected tuna oil.

* Corresponding author: Dr Soressa M. Kitessa, fax +61893878991, email Soressa.Kitessa@csiro.au

$\dagger$ Mailing address: CSIRO Livestock Industries, Underwood Ave, Floreat Park, Private Bag 5, Wembley, WA 6913, Australia.
} 
n-3 PUFA found in green feeds, namely linolenic acid, is extensively biohydrogenated by rumen bacteria.

Other studies have shown increases in the $n$-3 PUFA content of milk by feeding dairy cows with fish meal (Cant et al. 1997), marine algae (Franklin et al. 1999), fish oil and tuna oil (Offer et al. 1999). In almost all cases, however, feeding unprotected polyenoic lipids to cows was associated with adverse effects, such as decreased feed intake and milk yield (Palmquist et al. 1977; Cant et al. 1997), and decreased protein and/or fat content of milk (Cant et al. 1997; Rotunno et al. 1998; Franklin et al. 1999; Offer et al. 1999). The experiment reported here is one of a series of experiments on manipulation of fat from ruminant animal products through the use of rumen-protected lipids. In previous studies we have shown that while both protected and unprotected tuna-oil supplements enriched goats' milk with $n$-3 PUFA, only the protected supplement achieved this without depressing feed intake and milk yield or inducing undesirable changes in milk composition (Kitessa et al. 2001b). This was confirmed using a similar supplement in dairy sheep from which milk was significantly enriched with EPA and docosahexaenoic acid (DHA) without adversely influencing milk yield or composition (EPA + DHA constituted $24 \mathrm{~g} /$ kg milk fat; Kitessa et al. 2003). Recently, Gulati et al. (2003) reported similar levels of incorporation of EPA and DHA from protected tuna oil into cow's milk. The current study was conducted to determine if supplementing the diet of grazing dairy cows with rumen-protected tuna oil (RPTO) enriches milk with EPA and DHA without affecting flavour adversely.

\section{Materials and methods}

\section{Experimental design and feeding procedures}

Fourteen multiparous Holstein-Friesian cows in early lactation (mean lactation day 90) were divided into two groups (seven per group) and offered supplements with (+RPTO) or without (-RPTO) RPTO. The +RPTO group received a mixture of lucerne hay $(2 \mathrm{~kg})$, mill mix $(1 \mathrm{~kg})$ and tuna oil-soyabean $(2 \mathrm{~kg} ; 30: 70$, w/w) powder blended with molasses (80:20, w/w) once per $d$ (after morning milking, 06.00 hours). The - RPTO group were offered the same supplements without the tuna oil-soyabean-molasses powder. Both groups were fed in individual feeding stalls and then grazed together on a pasture separate from the main dairy herd. The pasture consisted of kikuyu (Pennisetum clandestinum)-perennial ryegrass (Lolium perenne) $(75: 25, \mathrm{w} / \mathrm{w})$ in the vegetative state. The tuna oil-soyabean supplement was protected from ruminal biohydrogenation by the use of formaldehyde as a tanning agent (Scott et al. 1971); the tuna oil-soyabean powder was coated with molasses to enhance palatability of the lipid supplement. The +RPTO cows received $671 \mathrm{mg} \alpha$-tocopherol per head per $\mathrm{d}$. The composition of supplemental ingredients is shown in Table 1. The total feeding period was $10 \mathrm{~d}$. No attempt was made to make the nutrients on offer for both groups of cows either isoenergetic or isonitrogenous, as the aim of the present study was to determine the pattern and rate of incorporation of $n-3$ PUFA from diet into milk.

\section{Milk yield, sample collection and analysis}

Cows were milked twice per d (06.00 and 15.00 hours) with a milking machine and total milk production per $\mathrm{d}$ was measured from two consecutive milkings (morning and afternoon). The volume of milk at each milking was determined using commercial milk meters (True Test Distributors, Auckland, New Zealand). Individual milk samples were collected at each milking and stored at $4^{\circ} \mathrm{C}$ for analysis. Total fat, protein, lactose and solids-not-fat content of milk samples were determined by using the mid-IR reflectance method (Milko-Scan 130 Series; Foss Electric, Hillerød, Denmark). The fatty acid composition of milk fat was determined following Christie's method (1989): extraction of total fat from a $5 \mathrm{ml}$ sample was achieved by adding $1 \mathrm{ml} \mathrm{NH}_{4} \mathrm{OH}$ solution, 5 M-ethanol and $12.5 \mathrm{ml}$ diethyl ether. This was followed by methylation using sodium methoxide (sodium methoxide-diethyl ether $(1: 1, \mathrm{v} / \mathrm{v}))$. Methyl esters were extracted by adding $2.5 \mathrm{ml}$ diethyl ether to the solution and removing a portion of the top phase into GC vials. Individual fatty acids were determined by analysis of their fatty acid methyl esters on

Table 1. Chemical composition of supplemental ingredients

\begin{tabular}{|c|c|c|c|c|}
\hline & Pellets & Lucerne hay & Mill mix & RPTO \\
\hline \multicolumn{5}{|l|}{ Component (g/kg DM) } \\
\hline Crude protein $(\mathrm{N} \times 6.25)$ & 190 & 180 & 179 & 304 \\
\hline Fat & 16 & 30 & 34 & 368 \\
\hline Acid-detergent fibre & 61 & 330 & 137 & 55 \\
\hline Neutral-detergent fibre & 153 & 550 & 509 & 479 \\
\hline \multicolumn{5}{|c|}{ Fatty acids ( $\mathrm{g} / 100 \mathrm{~g}$ total fatty acids) } \\
\hline Palmitic $(16: 0)$ & $18 \cdot 7$ & $23 \cdot 7$ & $17 \cdot 9$ & $19 \cdot 1$ \\
\hline Stearic $(18: 0)$ & 1.66 & 4.46 & 1.35 & 5.75 \\
\hline Oleic (cis-9-18:1) & $21 \cdot 1$ & 4.40 & $18 \cdot 9$ & $16 \cdot 5$ \\
\hline Linoleic $(18: 2 n-6)$ & $54 \cdot 1$ & $16 \cdot 8$ & $54 \cdot 1$ & 23.6 \\
\hline Linolenic $(18: 3 n-3)$ & 2.94 & $27 \cdot 4$ & 4.35 & 4.06 \\
\hline Arachidonic $(20: 4 n-6)$ & nd & nd & nd & 0.94 \\
\hline Eicosapentaenoic $(20: 5 n-3)$ & nd & nd & nd & $3 \cdot 24$ \\
\hline Docosahexaenoic $(22: 6 n-3)$ & nd & nd & nd & 11.6 \\
\hline
\end{tabular}

RPTO, rumen-protected tuna oil; nd, not detected. 
a Perkin-Elmer GC with a flame ionisation detector and fitted with BPX70 capillary column $(50 \mathrm{~m} \times 0.32 \mathrm{~mm}$ internal diameter with a bonded-phase film thickness of $0.25 \mu \mathrm{m}$; SGE Australia Pty Ltd, Sydney, New South Wales, Australia). Peak identification was achieved by comparing the retention times of individual peaks with those of authentic laboratory standard fatty acid methyl esters obtained from a commercial supplier (Sigma-Aldrich Pty Ltd). Selected samples were further analysed for peak confirmation by GC-MS, also using fatty acid methyl esters. The GC-MS was used to confirm the identity of peaks based on the number of double bonds. Fatty acid isomer identification was based on comparison with retention times of fatty acid methyl ester standards. Fatty acid analysis of feed and supplement samples was based on the saponification (hydrolysis) method (Christie, 1989). The reagents used were ethanol, $5 \mathrm{M}-\mathrm{NaOH}, 5 \mathrm{M}-\mathrm{H}_{2} \mathrm{SO}_{4}$, light petroleum (boiling point $38.8-48.6^{\circ} \mathrm{C}, 10 \mathrm{ml} \mathrm{H}_{2} \mathrm{SO}_{4} /$ 1 methanol (for methylation) and $50 \mathrm{~g} \mathrm{NaCl} / 1$ distilled water. Hydrolysis and saponification was performed by incubation at $80^{\circ} \mathrm{C}$ for $1.5 \mathrm{~h}$. Fatty acid profiles of feed and supplement samples were obtained using the GC described earlier. The GC was equipped with an auto-sampler with spilt injection. The carrier gas was He at a flow rate of $140 \mathrm{kPa}$. The detector temperature was set at $210^{\circ} \mathrm{C}$. The oven temperature programme was as follows: initial temperature of $150^{\circ} \mathrm{C}$, increased at $1^{\circ} \mathrm{C} / \mathrm{min}$ to $203^{\circ} \mathrm{C}, 45^{\circ} \mathrm{C} / \mathrm{min}$ to $250^{\circ} \mathrm{C}$ and held at that temperature for $14 \mathrm{~min}$. The atherosclerotic index for milk from the - RPTO and + RPTO groups was calculated using Ulbright \& Southgate's (1991) equation

$$
\begin{aligned}
& \text { atherosclerotic index } \\
& \begin{array}{l}
=\Sigma(12: 0+14: 0+16: 0) / \Sigma(n-3 \text { fatty acids } \\
\quad+n-6 \text { fatty acids }+ \text { oleic acid } \\
\quad+\text { other monounsaturated fatty acids }) .
\end{array}
\end{aligned}
$$

\section{Sensory evaluation}

The sensory evaluation was a single-blind test. Volunteers (n 61) were individually presented with four milk samples in small vials labelled A, B, C and D, representing full-fat milk from a supermarket, milk from + RPTO cows, fatreduced milk $(10 \mathrm{~g}$ fat $/ \mathrm{kg})$ from a supermarket and milk from - RPTO cows. + RPTO and - RPTO milks were pasteurised. The volunteers were asked to rate each milk sample on a scale from 1 (bad) to 5 (good) for flavour and smell. They were also asked to provide data on gender and whether or not they used milk regularly.

\section{Statistical analyses}

Treatment differences were determined by using Student's $t$ test using SYSTAT ${ }^{\circledR} 9$ (1999; SPSS Inc., Chicago, IL, USA). Differences in milk yield were determined based on data gathered during the whole feeding period, while milk composition, sensory evaluation and the fatty acid profiles of milk fat were compared in samples collected on the final $2 \mathrm{~d}$ (days 9 and 10 after feeding began). In both cases, the $t$ test was performed assuming samples from the two groups were independent samples with equal variance and with 12 df $\left(n_{1}+n_{2}-2\right)$. For the + RPTO treatment, the rate of transfer of EPA and DHA from diet to milk was calculated from values on day 10 for each cow, assuming all the EPA and DHA in milk was of dietary origin. Sensory data on flavour and smell were analysed using a single factor (milk source) ANOVA on the pooled data (see later).

All experimental protocols were approved by the CSIRO Animal Ethics Committee according to the recommendations of the Australian National Health and Medical Research Council.

\section{Results}

Supplement intake, milk yield and composition

Both groups of cows were held in the stalls until all the supplement was eaten. This took up to $90 \mathrm{~min}$ on the first $2 \mathrm{~d}$; after the second day their supplement was consumed in 30-45 min. Since they ate all the supplement on offer, intakes of supplement, added fat and tuna-oil-derived fatty acids were computed from the composition data in Table 1 and the amount offered. Accordingly, the intake of total added fat, EPA and DHA were 736, 23.8 and $85.4 \mathrm{~g} / \mathrm{kg} \mathrm{DM}$ per $\mathrm{d}$ respectively. There was no significant difference in milk yield between - RPTO (35.4 litres/d) and + RPTO (33.9 litres/d) groups (Table 2). Similarly, differences in fat (-RPTO $36 \cdot 2 v$. + RTPO $40.4 \mathrm{~g} / \mathrm{kg}$ ), protein (-RPTO $28 \cdot 2 v$. + RTPO $30 \cdot 1 \mathrm{~g} / \mathrm{kg}$ ), lactose (-RPTO $48.3 v .+$ RTPO $49 \cdot 0 \mathrm{~g} / \mathrm{kg}$ ) and solids-not-fat (- RPTO 83.6 $v$. + RTPO $86.3 \mathrm{~g} / \mathrm{kg}$ ) contents of milk were not significant, although in each case values were slightly higher for the + RPTO group (Table 2).

\section{Fatty acid composition of milk}

Detectable levels of EPA and DHA appeared in the milk from + RPTO cows $36 \mathrm{~h}$ after the start of feeding the supplement (Fig. 1). The concentrations of EPA and DHA in milk reached a plateau on day 6 at approximately 0.59 and $1.21 \mathrm{~g} / 100 \mathrm{~g}$ total fatty acids respectively and remained steady to the last day of feeding (Fig. 1). There was a coincidental increase in $\alpha$-linolenic acid $(18: 3 n-3)$ (Fig. 1). This caused a marked increase in the overall $n-3$

Table 2. Yield and composition of milk from cows with or without supplemention with rumen-protected tuna oil ${ }^{\star}$

(Mean values for seven cows per group)

\begin{tabular}{lccc}
\hline & \multicolumn{2}{c}{ Treatment diet } & \\
\cline { 2 - 3 } & - RPTO & + RPTO & SEM $\ddagger$ \\
\hline Milk yield (litres $/ \mathrm{d})$ & 35.4 & 33.9 & 0.63 \\
Fat $(\mathrm{g} / \mathrm{kg}) \dagger$ & 36.2 & 40.4 & 2.3 \\
Protein $(\mathrm{g} / \mathrm{kg}) \dagger$ & 28.2 & 30.1 & 0.8 \\
Lactose $(\mathrm{g} / \mathrm{kg}) \dagger$ & 48.3 & 49.0 & 0.9 \\
Solids-not-fat $(\mathrm{g} / \mathrm{kg}) \dagger$ & 83.6 & 86.3 & 1.4 \\
\hline
\end{tabular}

* For details of diets, supplements and procedures, see Table 1 and p. 272.

†Computed from composition values in Table 1 and the amount of supplement offered daily.

¥ Mean values within each row were not significantly different $(P>0.05)$. 


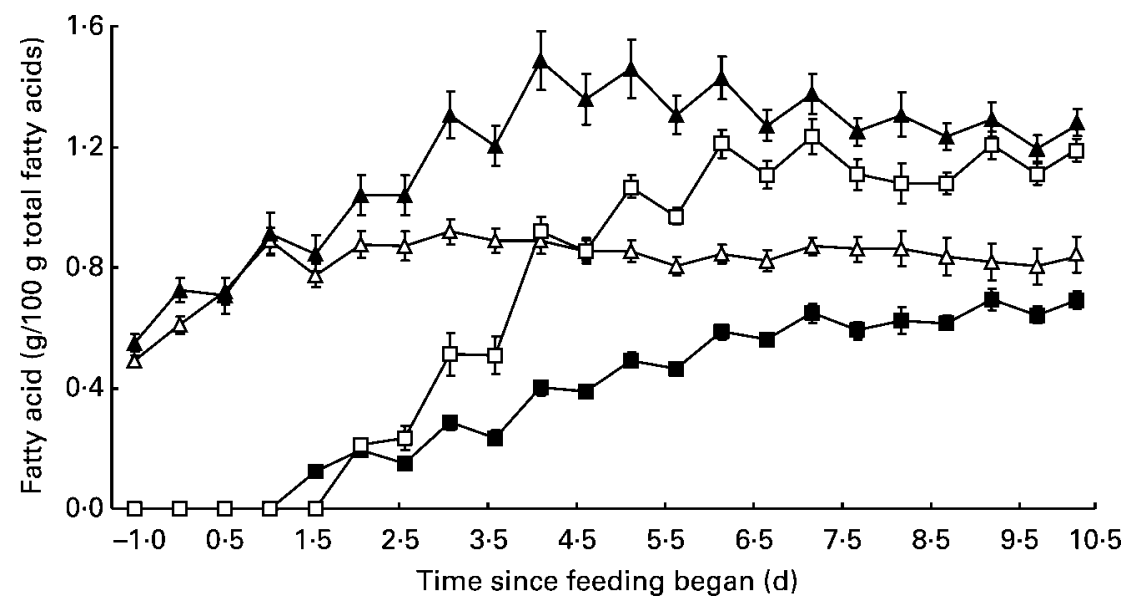

Fig. 1. Changes in the concentrations of $\alpha$-linolenic (LNA), EPA and docosahexaenoic acid (DHA) in milk fat from cows with or without supplementation with rumen-protected tuna oil (RPTO) while grazing spring pasture. $\triangle$, LNA (-RPTO); $\mathbf{\Lambda}$, LNA (+RPTO); $\mathbf{\square}$, EPA (+RPTO); $\square$, DHA (+RPTO). There was no detectable level of EPA or DHA in unsupplemented cows. For details of diets, supplements and procedures, see Table 1 and p. 272. Values are means with their standard errors shown by vertical bars (seven cows per group).

PUFA content of milk from the +RPTO group of cows; this was $3 \cdot 0-3.8$ times greater than that in - RPTO cows from day 4 onwards (Fig. 2). Neither EPA nor DHA was detected in the milk of - RPTO cows, and all the $n$-3 PUFA in their milk shown in Fig. 2 was $\alpha$-linolenic acid.

The comparative fatty acid composition of milk samples collected on day 10 from + RPTO and - RPTO cows is shown in Table 3. Most differences in the concentrations of individual fatty acids between + RPTO and - RPTO groups were highly significant (Table 3). Tuna oil-fed cows secreted significantly greater levels of fatty acids of twelve or more $\mathrm{C}$ atoms, lower concentrations of $16: 0,18: 0$, and cis-9-18:1, and higher concentrations of trans-18:1 (total), 18:2n-6, 20:4n-6, 20:5n-3 and $22: 6 n-3$ than - RPTO cows (Table 3 ). Total $n$-3 fatty acid contents of milk were 0.86 and $2.98 \mathrm{~g} / 100 \mathrm{~g}$ total fatty acids $(P<0 \cdot 01)$ and the $\Sigma n-6$ fatty acids: $\Sigma n-3$ fatty acids ratios were 3.31 and $2.31(P<0.001)$ for - RPTO and + RPTO groups respectively. Supplementation with tuna oil reduced the atherosclerotic index of milk fat by $17 \%(P<0 \cdot 01)$
Apparent efficiency of transfer of tuna-oil fatty acids into milk

The apparent transfer of EPA from diet to milk was nearly twice that of DHA. On average, about one-third of the EPA in diet was transferred to milk $(0 \cdot 32)$. The corresponding value for DHA was nearly one-sixth $(0 \cdot 18)$. The CV was similar for both estimates.

\section{Sensory evaluation}

There was no difference in the sensory data between gender or between those who used milk regularly or not. Pooled data are presented in Fig. 3. Accordingly, the preliminary consumer panel test on volunteers from our laboratory $(n$ 61) on milk samples collected $10 \mathrm{~d}$ after fish-oil supplementation began did not show any signs of an 'off' flavour or fish-oil flavour (Fig. 3). All milk samples scored similarly for smell. While the taste score was similar for the $n-3$ fatty acid-enriched and control milks, both of these samples were allocated lower scores than the full-fat and fat-reduced milk samples obtained

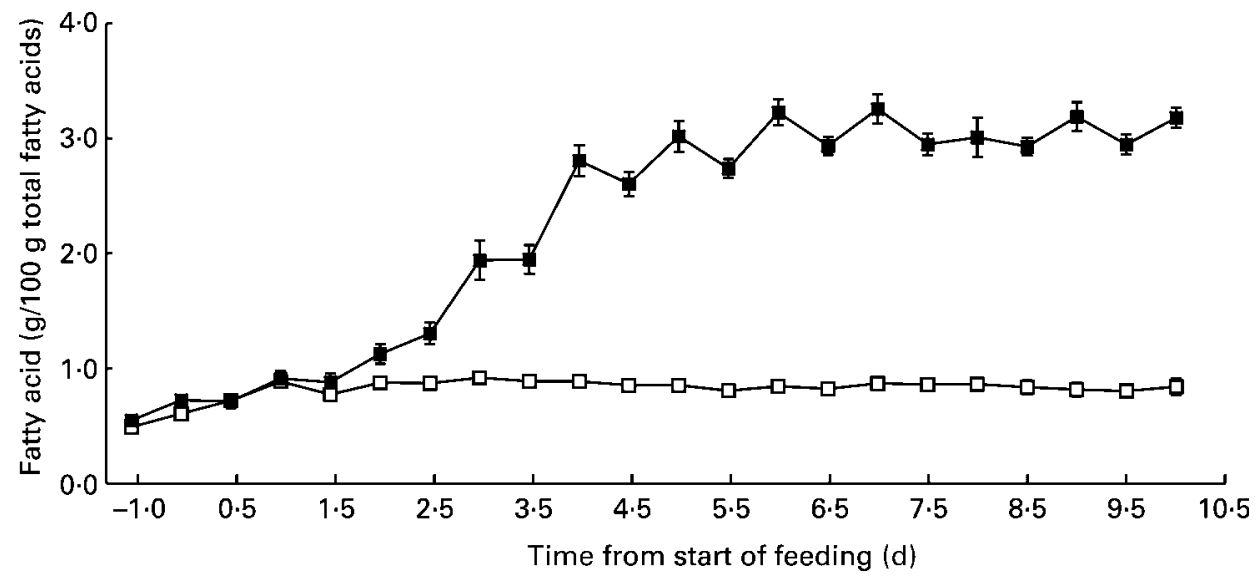

Fig. 2. Changes in the concentrations of total $n-3$ fatty acids $(18: 3 n-3+20: 5 n-3+22: 6 n-3)$ in milk fat from cows with ( $\square)$ or without ( $\square$ ) supplementation with rumen-protected tuna oil. Values are means with their standard errors shown by vertical bars (seven cows per group). 
Table 3. Fatty acid concentrations in milk from cows with or without supplemention with rumen-protected tuna oil $†$

(Mean values for seven cows per group)

\begin{tabular}{|c|c|c|c|}
\hline \multirow{2}{*}{$\begin{array}{l}\text { Fatty acids } \\
\text { (g/100 g total fatty acids) }\end{array}$} & \multicolumn{2}{|c|}{ Treatment diet } & \multirow[b]{2}{*}{ SEM } \\
\hline & - RPTO & + RPTO & \\
\hline $8: 0$ & 1.43 & 1.67 & $0.09^{*}$ \\
\hline $10: 0$ & $2 \cdot 30$ & 2.82 & $0 \cdot 15^{\star \star}$ \\
\hline $12: 0$ & $2 \cdot 36$ & 2.88 & $0 \cdot 17^{\star \star}$ \\
\hline $14: 0$ & 8.98 & 8.79 & $0.41 \ddagger$ \\
\hline $14: 1$ & 0.72 & 0.74 & $0.07 \ddagger$ \\
\hline $16: 0$ & $25 \cdot 6$ & $23 \cdot 0$ & $0.64^{\star \star *}$ \\
\hline $16: 1$ & 0.99 & 1.06 & $0.07 \ddagger$ \\
\hline $18: 0$ & $14 \cdot 7$ & 11.4 & $0.70^{\star \star \star}$ \\
\hline trans 18: 1 & 4.46 & $5 \cdot 81$ & $0.60^{\star}$ \\
\hline cis 18: 1 & $23 \cdot 7$ & $19 \cdot 7$ & $1 \cdot 03^{\star \star \star}$ \\
\hline $18: 2 n-6$ & 2.73 & 6.54 & $0.24^{\star \star *}$ \\
\hline $18: 3 n-3$ & 0.86 & $1 \cdot 28$ & $0.06^{\star \star *}$ \\
\hline $20: 0$ & $1 \cdot 37$ & 1.52 & $0.11 \neq$ \\
\hline $20: 4 n-6$ & 0.08 & 0.32 & $0.02^{\star \star *}$ \\
\hline $20: 5 n-3$ & 0.0 & 0.61 & $0.01^{\star * *}$ \\
\hline $22: 6 n-3$ & 0.0 & 1.09 & 0.01 *** \\
\hline$\sum n-6$ fatty acids : $\sum n-3$ fatty acids & 3.31 & $2 \cdot 31$ & $0.11^{\star \star *}$ \\
\hline Total saturated fatty acids & $56 \cdot 8$ & $52 \cdot 0$ & $0.95^{\star \star}$ \\
\hline Total unsaturated fatty acids & 33.9 & $38 \cdot 3$ & $0.95^{\star \star}$ \\
\hline Atherosclerotic index§ & $1 \cdot 11$ & 0.92 & $0.05^{\star \star}$ \\
\hline
\end{tabular}

RPTO, rumen-protected tuna oil. ${ }^{\star} P<0.05,{ }^{* \star} P<0.01,{ }^{* \star *} P<0.001$.

† Day 10 values; for details of diets, supplements and procedures, see Table 1 and p. 272.

$\ddagger$ Mean values within each row were not significantly different $(P>0.05)$. $\S$ Ulbright \& Southgate (1991): $\Sigma(12: 0+14: 0+16: 0) / \Sigma(n-3$ fatty acids + $n-6$ fatty acids + oleic acid + other monounsaturated fatty acids).

from a supermarket. A supplementary triangular panel taste in the certified sensory laboratory showed that panellists were unable to differentiate the $n-3$ fatty acid-enriched milk from the other two non- $n-3$ fatty acid-enriched milk samples (results not shown).

\section{Discussion}

\section{Milk yield and composition}

As in previous studies (Kitessa et al. 2001b, 2003; Gulati et al. 2002, 2003), feeding RPTO modified the fatty acid profile of milk without depressing milk yield or modifying

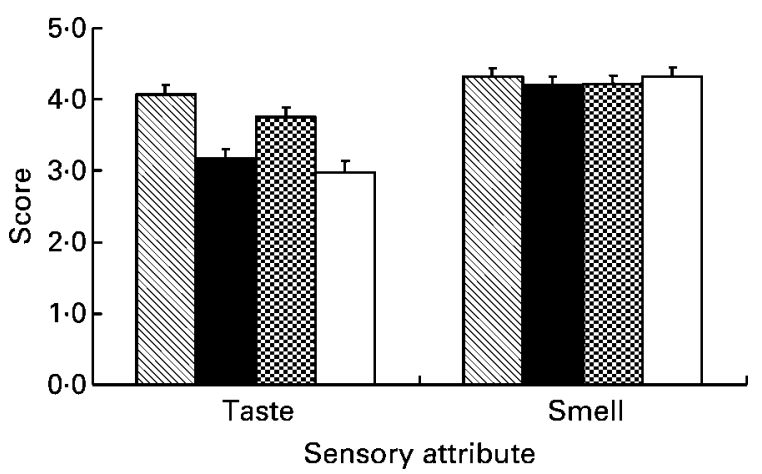

Fig. 3. Test panel scores for flavour and smell of milk samples presented in a single-blind test. Full-fat and fat-reduced milk samples were bought from a supermarket. Score 1 (bad) to 5 (good). $\mathbb{Q}$, Full-fat milk; $\mathbf{\square}$, milk from cows supplemented with rumen-protected tuna oil; 畻, fat-reduced milk; $\square$, milk from cows not supplemented with rumen-protected tuna oil. For details of milks and procedures, see p. 272. the concentrations of milk protein, fat and other milk solids. The results from the present study are also consistent with our observation in dairy goats (Kitessa et al. 2001b) and dairy sheep (Kitessa et al. 2003), in that the extra energy from the high metabolisable energy (ME) RPTO supplement (estimated as $17 \mathrm{MJ}$ ME/kg DM; Kitessa et al. 2001a) did not increase milk yield. The reason for this is unclear, but it may be due to substitution commonly observed in grazing animals offered a supplement of higher ME than pasture (Grainger \& Matthews, 1989); thus, cows offered the RPTO supplement may have consumed less pasture. As both groups were grazed together it was not possible to ascertain whether this was the case. Based on published ME requirements (Chamberlain \& Wilkinson, 1996) for milk with $40 \mathrm{~g}$ fat and $30 \mathrm{~g}$ protein $/ \mathrm{kg}$ (Table 2), the extra ME should have increased milk yield by approximately 6.5 litres $(2(\mathrm{~kg}) \times 0.9 \quad(\mathrm{DM}) \times 17 \quad(\mathrm{MJ} \mathrm{ME} / \mathrm{kg}) /$ 4.77). We did not measure the body condition score of the cows and cannot state whether or not the RPTO group may have used the extra ME to spare mobilisation of body reserve to support milk yield.

\section{Fatty acid composition of milk}

The pattern of incorporation of dietary tuna-oil fatty acids (EPA and DHA) into milk fat was similar to that reported earlier in dairy sheep (Kitessa et al. 2003), and confirms that the levels of EPA and DHA in milk fat reached a plateau after $6 \mathrm{~d}$ of supplementation with dietary sources of EPA and DHA. More importantly, in one cup $(250 \mathrm{ml})$ of full-cream milk the level of enrichment of milk with EPA and DHA achieved in the present study provided $26 \%$ of the recommended daily allowance for $n-3$ PUFA (650 mg; Simopoulos et al. 1999). Such enrichment was achieved without adversely affecting milk yield, composition or sensory characteristics. The concentration of $\mathrm{EPA}+\mathrm{DHA}$ in milk fat recorded in the present study was greater than that reported in most other studies (Table 4). Although Cant et al. (1997) achieved greater enrichment of milk fat with EPA and DHA (Table 4), the enrichment was accompanied by reduced intake and milk yield, a response that was avoided in the present and previous studies (Kitessa et al. 2001b, 2003) by using a protected form of these supplements. Our untrained consumer-panel results support trained consumer-panel results reported earlier, in that no flavour differences were found in milk from cows supplemented with fish oil (Ramaswamy et al. 2003). Although we did not make products from our milk, observations from other studies (Gulati et al. 2002; Avramis et al. 2003) indicated the benefits of fish-oil fatty acid-enrichment for improved butter quality, as butter from fish-oil fatty acid-enriched milk was characterised as having a soft texture and better spreading characteristics when cold.

There were both common trends and discrepancies in comparative changes in milk fatty acids following fish-oil supplementation in different experiments (Table 5). Generally, the concentrations of stearic acid $(18: 0)$ and, to a lesser extent, oleic acid levels (cis-18:1) were significantly decreased due to fish-oil supplementation. On the other hand, the concentration of trans-18:1 was consistently 
Table 4. The effect of dietary supplemention with EPA and docosahexaenoic acid in dairy cows on concentrations in milk (Mean values)

\begin{tabular}{|c|c|c|c|c|c|c|c|}
\hline \multirow[b]{2}{*}{ Basal diet } & \multirow[b]{2}{*}{ Added fat $(\mathrm{g} / \mathrm{d})$} & \multirow[b]{2}{*}{ Rumen-protected } & \multicolumn{2}{|c|}{$\begin{array}{l}\text { Fatty acid } \\
\text { (g/kg fat in } \\
\text { diet) }\end{array}$} & \multicolumn{2}{|c|}{$\begin{array}{c}\text { Fatty acid } \\
\text { (g/kg fat in } \\
\text { milk) }\end{array}$} & \multirow[b]{2}{*}{ Reference } \\
\hline & & & EPA & DHA & EPA & DHA & \\
\hline Green pasture & 730 & Yes & 32.4 & 116 & 6.9 & $10 \cdot 1$ & Present study \\
\hline Pasture & 1143 & Yes & 35.5 & $169 \cdot 3$ & $12 \cdot 5$ & 21.9 & Gulati et al. (2003) \\
\hline Mixed ration & $699^{*}$ & No & $15 \cdot 3$ & $45 \cdot 4$ & - & $7 \cdot 6$ & Franklin et al. (1999) \\
\hline Mixed ration & $568 \dagger$ & No & - & - & 10 & $18 \cdot 7$ & Cant et al. (1997) \\
\hline Silage & 450 & No & $7 \cdot 3$ & 9.7 & $5 \cdot 3$ & 1.7 & Keady et al. (2000) \\
\hline Silage & 250 & No & 38.9 & $20 \cdot 3$ & 1.1 & 0.84 & Offer et al. (1999) \\
\hline Silage-hay & 470 & No & 33.0 & $24 \cdot 8$ & 3.2 & 2.6 & Donovan et al. (2000) \\
\hline
\end{tabular}

DHA, docosahexaenoic acid.

${ }^{*}$ Amount of protected marine algae supplement in mixed ration (DM intake $17.6 \mathrm{~kg} / \mathrm{d}$, algae supplement $39.7 \mathrm{~g} / \mathrm{kg} \mathrm{DM}$ ).

† Added redfish oil Sebastes marinus (DM intake $14.2 \mathrm{~kg} / \mathrm{d}$, redfish oil $40 \mathrm{mg} / \mathrm{kg} \mathrm{DM}$ ).

$\ddagger$ Computed from values for a treatment that had $20 \mathrm{~g}$ fish oil $/ \mathrm{kg}$ and $23.5 \mathrm{~kg} \mathrm{DM}$ intake $/ \mathrm{d}$.

greater in fish-oil-supplemented groups. These trends may be a reflection of interference of fish-oil supplementation with the complete hydrogenation of $\mathrm{C}_{18}$ unsaturated fatty acids to $18: 0$. The increase in both $18: 2$ and $18: 3$ concentrations may also have been in part due to additional supply of $18: 2$ and $18: 3$ from the supplement originating from its soyabean component. Changes in the concentrations of palmitic acid $(16: 0)$ in different experiments were inconsistent, in that they remained similar in unsupplemented and supplemented groups (Offer et al. 1999; Donovan et al. 2000; Baer et al. 2001), were reduced in supplemented groups (present study; Keady et al. 2000) or were greater in supplemented groups (Cant et al. 1997; Franklin et al. 1999). The rationale behind the lack of congruencies is difficult to determine, but may relate to the difference in the basal rations used in the different experiments, as about 50\% 16:0 in milk is of dietary origin (Moore \& Christie, 1979). In addition, differences in the stage of lactation and degree of mobilisation of body fat reserves may contribute to this variation in experimental results.

In the present study, fish-oil supplementation significantly increased the levels of short- to medium-chain fatty acids $(8: 0,10: 0$ and $12: 0)$, which contradicted the decrease in these fatty acids reported elsewhere following fish-oil supplementation (Donovan et al. 2000; Keady et al. 2000; Baer et al. 2001; Ramaswamy et al. 2003). Fatty acids in milk with less than fourteen $\mathrm{C}$ atoms originate from endogenous synthesis in the mammary gland (Moore \& Christie, 1979); this synthesis relies on the supply of acetate and butyrate from the rumen.

In all studies there was significant shift in the indicators of potential health benefit from milk due to fish-oil supplementation of cows; that is, a decrease in total saturated fatty acids, an increase in total unsaturated fatty acids and a decrease in atherosclerotic index were achieved. Furthermore, the variation in levels of enrichment with $n-3$ PUFA among experiments indicates there is scope for improving the rumen-protection technology, although any further enrichment may lead to flavour taint.

Apparent efficiency of transfer of tuna-oil fatty acids into milk

The apparent efficiency of transfer of dietary DHA into milk $(0 \cdot 18)$ observed in the present study was similar to

Table 5. Changes in milk fatty acid profiles recorded in different experiments following supplementation of dairy cows with fish oil

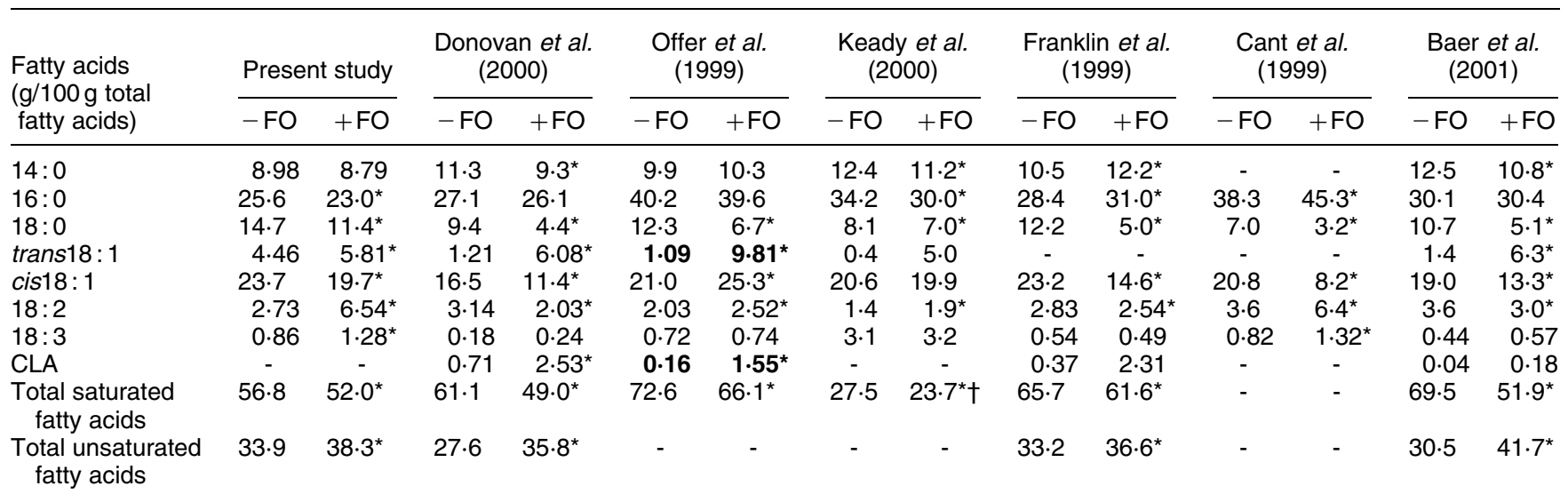

FO, fish oil; CLA, conjugated linoleic acid.

* Significant variations from control values.

†Total saturates only encompassing 4:0-14:0. 
that reported by Kitessa et al. (2003) in dairy sheep and by Gulati et al. (2002, 2003) in dairy cows; all the studies used RPTO supplement. It was also comparable with the level (0.16) reported by Cant et al. (1997). The incorporation of EPA $(0 \cdot 32)$ observed in the present study was greater than the 0.21 recorded for dairy sheep (Kitessa et al. 2003) and dairy cattle (0.09) (Cant et al. 1997; Gulati et al. 2002, 2003). It should be noted that EPA in milk can be sourced from dietary EPA per se or retroconversion of DHA to EPA (Gulati et al. 2003). Future studies need to consider the effect of different basal dietary ingredients on the efficiency of transfer of dietary EPA and DHA.

\section{Acknowledgements}

Tuna oil was provided by Clover Corporation Ltd, Australia. We would like to thank staff volunteers who took part in the sensory evaluation. Streets Ice Cream, Sydney, Australia, kindly helped with pasteurisation of milk samples for consumer panel tests. We acknowledge the assistance of Mr Kim McKean and other staff of the University of Sydney's Camden Dairy Farm.

\section{References}

Avramis CA, Wang H, McBride BW, Wright TC \& Hill RA (2003) Physical and processing properties of milk, butter and cheddar cheese from cows fed supplemental fish meal. $J$ Dairy Sci 86, 2568-2576.

Baer RJ, Ryali J, Schingoethe DJ, et al. (2001) Composition and properties of milk and butter from cows fed fish oil. J Dairy Sci 84, 345-353.

Cant JP, Fredeen AH, MacIntyre T, Gunn J \& Crowe N (1997) Effect of fish oil and monesin on milk composition in dairy cows. Can J Anim Sci 77, 125-131.

Chamberlain AT \& Wilkinson JM (1996) Feeding the Dairy Cow, pp. 101-106. Lincoln, Lincs.: Chalcombe Publications.

Christie WW (1989) Gas Chromatography and Lipids. A Practical Guide, pp. 66-68. Ayr: The Oily Press.

Donovan DC, Schingoethe DJ, Baer RJ, et al. (2000) Influence of dietary fish oil on conjugated linoleic acid and other fatty acids in milk fat from lactating dairy cows. J Dairy Sci 83, $2620-2628$.

Franklin ST, Martin KR, Baer RJ, Schingoethe DJ \& Hippen AR (1999) Dietary marine algae (Schizochytrium sp.) increases concentrations of conjugated linoleic, docosahexaenoic and transvaccenic acids in milks of dairy cows. J Nutr 129, $2048-2052$

Grainger C \& Matthews GL (1989) Positive relation between substitution rate and pasture allowance for cows receiving concentrates. Aust J Exp Agric 29, 355-360.

Gulati SK, McGrath S, Wyn PC \& Scott TW (2003) Preliminary results on the relative incorporation of docosahexaenoic and eicosapentaenoic acids into cows milk from two types of rumen protected fish oil. Int Dairy J 13, 339-343.

Gulati SK, May C, Wynn PC \& Scott TW (2002) Milk-fat enriched in n-3 fatty acids. Anim Feed Sci Technol 98, $143-152$.

Hoffman DR, Birch EE, Birch DG \& Uauy RD (1993) Effect of supplementation with $n-3$ long chain polyunsaturated fatty acids on retinal and cortical development in premature infants. Am J Clin Nutr 57, Suppl., 807S-812S.

Keady TWJ, Mayne CS \& Fitzpatrick DA (2000) Effects of supplementation of dairy cattle with fish oil on silage intake, milk yield and milk composition. J Dairy Res 67, 137-153.

Kitessa SM, Gulati SK, Ashes JR, et al. (2001a) Utilisation of fish oil in ruminants. I. Fish oil metabolism in sheep. Anim Feed Sci Technol 89, 189-199.

Kitessa SM, Gulati SK, Ashes JR, et al. (2001b) Utilisation of fish oil in ruminants. II. Transfer of fish oil fatty acids into goat's milk. Anim Feed Sci Technol 89, 201-208.

Kitessa SM, Peake D, Bencini R \& Williams AJ (2003) Fish oil metabolism in ruminants. III. Transfer of $n-3$ polyunsaturated fatty acids (PUFA) from tuna oil into sheep's milk. Anim Feed Sci Technol 108, 1-14.

Moore JH \& Christie WW (1979) Lipid metabolism in the mammary gland of ruminant animals. Prog Lipid Res 17, $347-395$.

Morgan C, Stammers J, Colley J, Spencer SA \& Hull D (1998) Fatty acid balance studies in preterm infants fed formula milk containing long-chain polyunsaturated fatty acids (LCP) II. Acta Paediatr 87, 318-324.

Nord $\varnothing$ y A, Marchioli R, Arnesen H \& Videbæ J (2001) n-3 Polyunsaturated fatty acids and cardiovascular health. Lipids 36, Suppl., S127-S129.

Offer NW, Marsden M, Dixon J, Speake BK \& Thacker FE (1999) Effect of dietary fat supplements on levels of $n-3$ poly-unsaturated fatty acids, trans acids and conjugated linoleic acid in bovine milk. Anim Sci 69, 613-625.

Palmquist DL, McClure KE \& Parker CF (1977) Effect of protected saturated or polyunsaturated fat fed to pregnant and lactating ewes on milk composition, lamb plasma fatty acids and growth. J Anim Sci 45, 1152-1159.

Ramaswamy N, Baer RJ, Schingoethe DJ, et al. (2003) Composition and flavour of milk and butter from cows fed fish oil, extruded soybeans or their combinations. J Dairy Sci 84, $2144-2151$

Rotunno T, Sevi A, Di Caterina R \& Muscio A (1998) Effect of graded levels of dietary rumen-protected fat on milk characteristics of Comisana ewes. Small Rumin Res 30 , 137-145.

Scott TW, Cook LJ \& Mills SC (1971) Protection of dietary polyunsaturated fatty acids against microbial hydrogenation in ruminants. J Am Oil Chem Soc 48, 358-364.

Sheard NF (1998) Fish consumption and risk of sudden cardiac death. Nutr Rev 56, 177-179.

Simopoulos AP (1991) Omega-3 fatty acids in health and disease and in growth and development. Am J Clin Nutr 54, 438-463.

Simopoulos AP, Leaf A \& Salem N Jr (1999) Workshop on the essentiality of and recommended dietary intakes for omega-6 and omega-3 fatty acids. Food Aust 51, 3332-3333.

SPSS Inc. (1999) SYSTAT ${ }^{\circledR}$ 9. Statistics I, pp. 430-434. Chicago, IL: SPSS Inc.

Ulbright TLV \& Southgate DAT (1991) Coronary heart disease: seven dietary factors. Lancet 338 985-992. 